\title{
体験教育旅行における受入農家民泊の普及過程に関する研究
}

一滋賀県東近江市愛東地区を事例として一

\author{
坊安恵（京都府立大学大学院） \\ 中村 貴子 (京都府立大学)
}

\section{Diffusion Structures of Farmer Inns that Host Experience-based Education Tours: A Case Study in the Aito Area of Higashiomi City, Shiga}

\author{
Yasue Bo (Kyoto Prefectural University) \\ Takako Nakamura (Kyoto Prefectural University)
}

This study seeks to clarify the diffusion structures of farmer inns that host experience-based education tours in the Aito area of Higasiomi city, Shiga. They involve invitations put forth by the farmer inns themselves, and a diffusion process that mainly involves local inhabitants. In outlining this solicitation route, we determined the following by

\section{1. はじめに}

近年, 学校教育に扔いて生きる力が重視される中, 2008 年から, 総務省・文部科学省・農林水産省の 3 省連携で「子ども農山漁村交流プロジェクト」事業 が開始されており, 農家での宿泊体験と農業体験が 子どもの生きる力に重要な役割を果たすことが報告 されている ${ }^{1)}$. 鈴村 ${ }^{2)}$ は小中学生を対象とした農家 民泊を含む一連の農林漁業体験プログラムを体験教 育旅行と位置付けて和り, 本稿でもこの定義に沿っ た体験教育旅行の取組を分析する. 体験教育旅行に 関する研究には，鈴村（2009），鈴村他（2010），山 田（2008a，2008b）佐藤（2008，2010）らによる研 究がみられるが，子どもの学習効果に関する研究が 多く, 一部に, 体験教育旅行の受入れによる地域活 性化に関する研究はみられるが，子ども達を受入れ る農家に関する研究は少ない。また体験教育旅行を 実践する場合，受入れ農家民泊の確保が必要である が，農家民泊の研究に执いては，中尾（2008，2009）， 大江 (1997), 佐藤（2009）らによる研究がみられ るものの, 農家民泊と農政との関わりや経営視点か らの研究はあるが，農家民泊の普及に関する研究は みられない, そこで本研究では，体験教育旅行を受 undertaking interview-based surveys: (1) There is a history of exchange projects just former Aito Town, (2) The diffusion process involved invitations by a few key persons, that is, dyadic ties, and (3) The diffusion structure had characteristics that changed according to the year in which the farmer inn hosted the tour.

入れる農家民泊の普及過程について研究する.

な抒，体験教育旅行の農家民泊の普及に関寸る 記述は，事例報告の一部としてみられるが，それ によれば，農家民泊の普及については，市町村自 治体がリーダーシップを発揮して進めているとこ ろが多い3．しかし，国の推進もあって，わずかで はあるが，今日，住民が主体となって農家民泊を普 及寸る地域もみられて和り，今後，そらした地域も 増えると考兄られる。 こうした実態を受けて本研究 では，先進的に住民主体で農家民泊の普及を行って きた滋賀県東近江市愛東地区を対象とし，第 1 亿農 家民泊の勧誘経路を明らかにすること，第 2 に農家 民泊の普及と，住民間の日常的な活動との関わりに ついて分析することで，受入農家民泊の住民主体に よる普及過程を明らかにする。な拈, 分析データは, 愛東地区で 2010 年以降に体験教育旅行の受入を 行ったことのある農家にヒアリング調査を行った結 果を用いる。

\section{2. 調查先の地域概要}

\section{(1) 地域概要}

滋賀県東近江市は，滋賀県南東部に位置する人口 
115,479 人, 38,941 世帯（資料： 2010 年国勢調査） の市である. 2010 年農林業センサスによれば, 販 売農家数 3,839 戸，自給的農家数 769 戸で, 耕地面 積は田が 6,398 ha，畑 131 ha，樹園地 48 ha となっ て沏り，大部分が水田の稲作地帯である。な打東近 江市は，2005 年に 1 市 4 町，翌 2006 年に 2 町と合 併した旧 1 市 6 町を包括する市である.

\section{（2）東近江市の受入状況}

体験教育旅行の受入の経緯は, 2010 年に体験教育 旅行の先進地で隣接する日野町から, 日野町での受 入上限を超えたため, 東近江市に中学生の受入要請 があったことに始まる，その当時，市の受入体制が なかったため, 東近江ハンドシェーク協議会（以下, ハンドシェーク)が試行的に受入れることとなった. ハンドシェークとは, 都市農村交流を目的に農林水 産省助成金の受入団体として結成された住民主導型 の組織である.この 1 回目の受入に関して地元での 評判が上々であったことを受けて，市長が市を挙げ て宿泊体験活動の受入れを行らと表明し，2011 年 2 月，「東近江市体験交流型旅行協議会」が設立され， 2011 年から体験教育旅行の受入を本格的に行って いる. 体験教育旅行の受入者数は, 2010 年 66 人, 2011 年 283 人, 2012 年 342 人で, 延べ 691 人, 5 ち愛東地区では, 2010 年 30 人, 2011 年 148 人, 2012 年 176 人で, 延べ 354 人の受入を実施して拉 り（表 1), 市の受入数の約半数を受入れている重要 な地区といえる.

\section{（3）愛東地区の特徵}

愛東地区の受入集落は, 23 集落のらち 18 集落で ある、つまり，汪とんどの集落で受入れている。こ れには，愛東地区，すなわち旧愛東町時代から続く 取組「愛のまち交流協会」による交流活動や国際交 流を積極的に受入れてきたことが影響していると考 えられる. 愛のまち交流協会の活動とは, 交流を進

\section{表 1. 東近江市での体験教育旅行の受入実績}

\begin{tabular}{|c|c|c|c|c|c|c|}
\hline & \multicolumn{3}{|c|}{ 受入人数 (A) (単位 : 人) } & \multicolumn{3}{|c|}{ 受入延世帯数 (C) (単位:戸) } \\
\hline & & 愛東 $(\mathrm{B})$ & $\mathrm{B} / \mathrm{A}$ & & 愛東 $(\mathrm{D})$ & $\mathrm{D} / \mathrm{C}$ \\
\hline 2010 年 & 66 & 30 & 45.5 & 20 & 9 & 45.0 \\
\hline 2011 年 & 283 & 148 & 52.3 & 82 & 45 & 54.9 \\
\hline 2012 年 & 342 & 176 & 51.5 & 105 & 51 & 48.6 \\
\hline 合計 & 691 & 354 & 51.2 & 207 & 105 & 50.7 \\
\hline
\end{tabular}

資料 : 東近江市体験交流型旅行協議会, 及び東近江市ハンドシェー ク協議会からのヒアリング調査に基づき筆者作成
める自治体間で毎年何名かの住民が往来し民泊が行 われるといらものである. 愛東地区の住民は，こうし た民泊を受入れていたといら経験を持つため，中学生 の受入についても抵抗感が少なかったと考兄られる.

\section{3. 受入農家民泊の普及過程 （1）受入農家民泊の意向}

2012 年 6 月〜 7 月にかけて，2010 年以降に農家 民泊の受入を 1 回以上行った世帯 47 戸を調査対象 とし，ヒアリング調査の承諾が得られた世帯 31 戸 (66.0\%)，34 人から回答を得た。な拉，農家民泊の 勧誘経路を分析対象とすることから，同世帯でも異 なる针誘経路を持つ者がいる場合には，1 世帯で複 数のヒアリング対象者がいる. そのため, ヒアリン グ調査対象者数は 31 人ではなく 34 人となっている.

ヒアリング調查対象者の属性については, 男性 13 人 $(39.4 \%)$ ，女性 20 人 $(60.6 \%)$ であり，年代は 60 歳代 16 人 (47.1\%), 50 歳代 9 人 (26.5\%), 40 歳代以下と 70 歳代以上がそれぞれ 4 人 (11.8\%) となっており，50～60 歳代で $73.5 \%$ と高い割合を 占めている.

な技, 受入世帯像をみると, 農業形態については, 専業農家が 3 戸 (9.7\%), 兼業農家が 12 戸 (38.7\%), 自給的農家が 15 戸 (48.4\%), 非農家が 1 戸 (3.2\%) である、また，農家民泊の受入中心人物の属性につ いては, 31 戸のらちの 18 戸 (58.1\%) が女性であり, 年代は 60 歳代が最も多く 13 人 $(41.9 \%), 50$ 歳代 が 9 人 (29.0\%) と続いて抒り，50〜 60 歳代が $70.9 \%$ と高い割合を占めていることがわかった．な

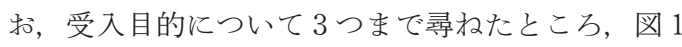
のように，(1)来訪者との交流を楽し屯ためが 27 戸 (87.1\%), (2)受入依頼に応じるためが 22 戸 $(71.0 \%)$, (3)愛東地区を知ってもららためが 21 戸 (67.7\%) となった ${ }^{4)}$. (2)の受入依頼に応じることについては, 同時に責任感を伴うことでもあるといらことがヒア リング調査から聞き取られた。

以上のことから, 農家民泊の主な受入世帯像は, $50 \sim 60$ 歳代の女性が中心的に行動し，交流好きで 責任感があり, 愛東地区への地域愛が強い世帯と考 えることができる。

\section{（2）普及過程の分析 \\ 1）勧誘経路の特徵}

ヒアリング調查より勧誘の構造を図式化したのが 
$0.0 \% \quad 20.0 \% \quad 40.0 \% \quad 60.0 \% \quad 80.0 \% \quad 100.0 \%$

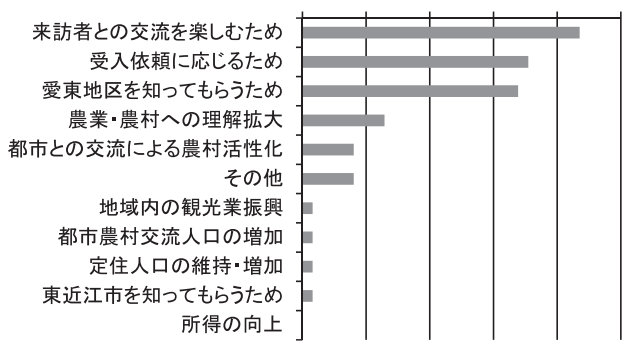

図 1. 体験教育旅行の受入目的

資料：ヒアリング調査に基づき筆者作成

註 : 受入主体者による複数回答 $(\mathrm{N}=31)$

図 2 である. 図 2 より勧誘の矢印の総数は 32 件で あるが，誘われた者が別の者を誘った件数は，この らちわずか 1 件（ハンドシェーク $\rightarrow \mathrm{H} 2 \rightarrow \mathrm{H} 3 ）$ で あり，ほとんどの人物は勧誘を行っていないといえ る。つまり，当地区での農家民泊の普及過程は，リ レー方式によるものではなく，農家民泊事業の普及 に沶いて中心的な役割を果たす 4 名とハンドシェー クからの勧誘によるものといえ, 農家民泊の普及構 造は，少数の中心人物と勧誘される世帯との二者間 関係によって成立していることが明らかとなった。 つまり，この 4 名が農家民泊の普及に打けるキー
パーソンである.この 4 名の勧誘行為に焦点をあて, 各々の二者間関係についてみることにする.

\section{2）勧誘者 4 名の特徵}

まずは，勧誘者 4 名によって 3 年間に蓄積された農 家民泊の普及過程から 4 名の行為について分析する.

表 2 はこの 4 名と勧誘された側との二者間関係に ついて記している. 第 1 列は勧誘者，第 2，3 列は勧 誘された者とその開始時期を示している．第 4 列は 居住地の二者間関係を示しており，集落内，学区内， 学区外に分類した ${ }^{5}$. 集落内とは同じ集落内の二者 間関係を指し，学区内とは異なる集落で同じ学区内 の二者間関係を指す。学区外とは異なる学区間の二 者間関係である。な拈，学区とは小学校区の意味て ある. 第5 列は勧誘者が考学る勧誘のきっかけとなっ た二者間関係を示している．個人的つながり以外の 二者間関係は全て組織活動の二者間関係による.

勧誘数でみると，D1 と D2 の勧誘数は N1 と D3 よりも多い. D1 と D2 は夫婦であり， $64.0 \%$ のが この世帯から勧誘されていることになる. D1 は元 愛東町長であることから，地域愛が人一倍強いと考 えられる. また, 旧愛東町時代から交流を盛んに行っ てきた主導者でもあり，中学生を受入れる本事業に

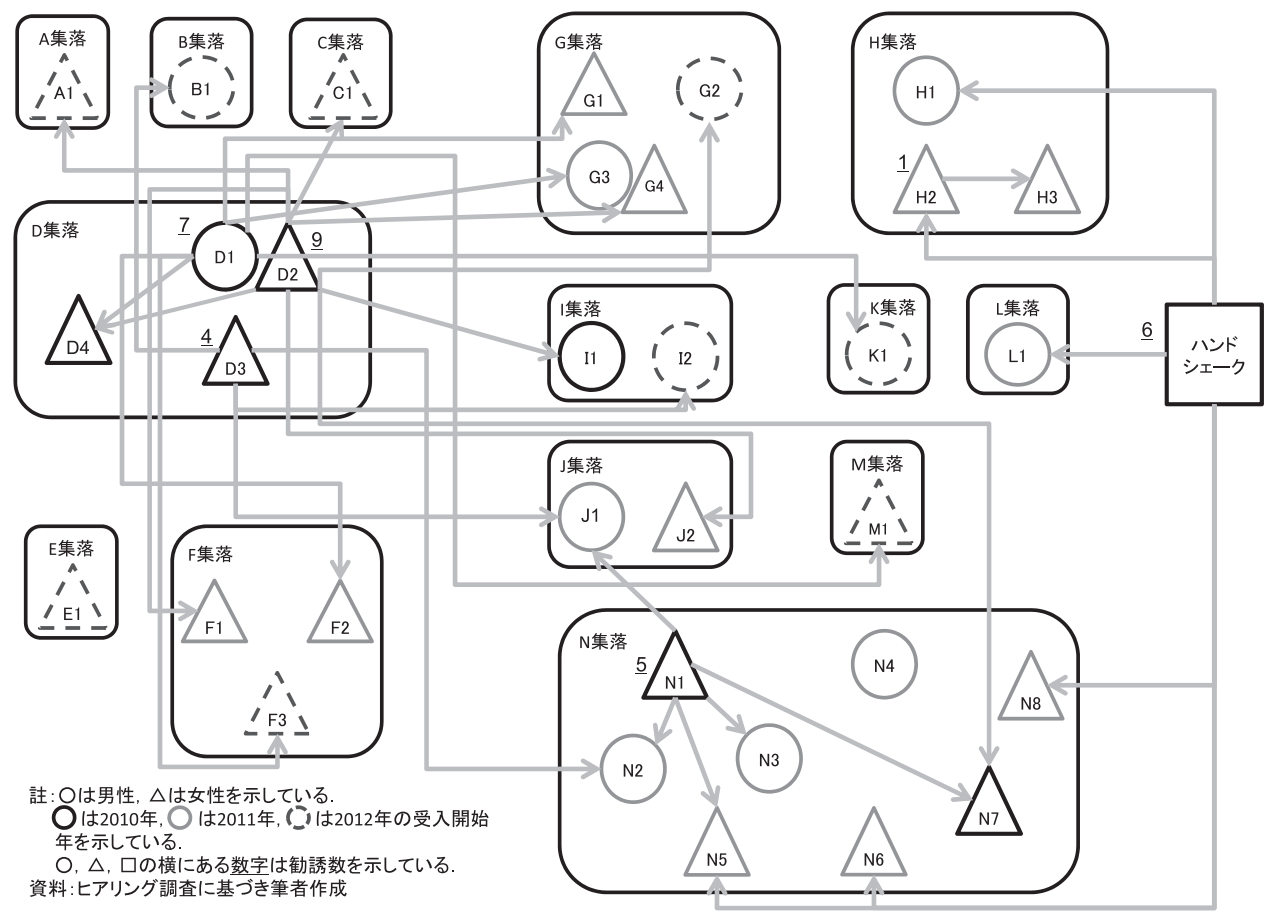

図 2. 愛東地区内での農家民泊者の受入契機とその勧誘経路 
表 2. 主要 4 名との勧誘された者との二者間関係

\begin{tabular}{|c|c|c|c|c|}
\hline $\begin{array}{l}\text { 勧誘者 } \\
\text { (出身地) }\end{array}$ & 勧誘された者 & 開始時期 & 居住地 ${ }^{1)}$ & 勧誘のきっかけとなった二者間関係 \\
\hline \multirow{9}{*}{$\begin{array}{c}\text { D2 } \\
\text { (八日市地区) }\end{array}$} & $\mathrm{D} 4$ & 2010 & 集落内 & ふきのとう（ボランティア的活動） \\
\hline & I1 & 2010 & 学区外 & 強い個人的つながり ${ }^{2)}$ \\
\hline & N7 & 2010 & 学区外 & 東近江ハンドシェーク協議会（ボランティア的活動） \\
\hline & F1 & 2011 & 学区内 & 強い個人的つながり \\
\hline & G4 & 2011 & 学区外 & 民生委員（ボランティア的活動） \\
\hline & $\mathrm{J} 2$ & 2011 & 学区外 & 愛のまち交流協会（ボランティア的活動） \\
\hline & $\mathrm{A} 1$ & 2012 & 学区内 & JA \\
\hline & $\mathrm{C} 1$ & 2012 & 学区内 & 弱い個人的つながり \\
\hline & G2 & 2012 & 学区外 & 民生委員（ボランティア的活動） \\
\hline \multirow{7}{*}{$\begin{array}{c}\text { D1 } \\
\text { (D 集落) }\end{array}$} & $\mathrm{D} 4$ & 2010 & 集落内 & 強い個人的つながり \\
\hline & $\mathrm{F} 2$ & 2011 & 学区内 & 愛のまち交流協会（ボランティア的活動） \\
\hline & G1 & 2011 & 学区外 & 愛東文化協会（公民館活動・ボランティア的活動） \\
\hline & G3 & 2011 & 学区外 & （財）愛の田園振興公社 \\
\hline & F3 & 2012 & 学区内 & 弱い個人的つながり \\
\hline & K1 & 2012 & 学区外 & 愛のまちエコ俱楽部（ボランティア的活動） \\
\hline & M1 & 2012 & 学区外 & 弱い個人的つながり \\
\hline \multirow{5}{*}{$\begin{array}{c}\mathrm{N} 1 \\
\text { (J 集落) }\end{array}$} & N7 & 2010 & 集落内 & 強い個人的つながり \\
\hline & J1 & 2011 & 学区内 & よさこい（ボランティア的活動） \\
\hline & $\mathrm{N} 2$ & 2011 & 集落内 & ずぼら会 \\
\hline & N3 & 2011 & 集落内 & 強い個人的つながり \\
\hline & N5 & 2011 & 集落内 & ずぼら会 \\
\hline \multirow{4}{*}{$\begin{array}{c}\text { D3 } \\
\text { (N 集落) }\end{array}$} & J1 & 2011 & 学区外 & 消防活動関係（ボランティア的活動） \\
\hline & $\mathrm{N} 2$ & 2011 & 学区外 & 強い個人的つながり \\
\hline & B1 & 2012 & 学区内 & 弱い個人的つながり \\
\hline & $\mathrm{I} 2$ & 2012 & 学区外 & 消防活動関係（ボランティア的活動） \\
\hline
\end{tabular}

資料：ヒアリング調査に基づき筆者作成

註 1 : 学区内とは，異なる集落で同じ学区内の範域とし，学区外とは，異なる学区間の範域とする.

註 $2:$ 強い個人的つながりとは，個人的相談や組織活動のこと以外でも連絡しあう仲のことであり，弱い個人的つながり とは，組織活動など義務的な活動のみを一緒にする仲のことである.

も最も主体的に関わっている人物とい光，中学生を 受入れた世帯には, 毎年, 年度替わりにハンドシェー クと共に訪問し，再度の受入を依頼するといった フォローアップも実施している。一方，D2 は頼み やすい家庭環境であることやボランティア活動をし ている人など受入を承諾してくれそうな世帯を中心 に勧誘していることがヒアリング調査から聞かれ た. 2010 年に始めた時には，D2 自身と日常的に強 いつながりのある友人やボランティア仲間など同じ 価値観を持つ友人を誘ったということだが，3 年目 の 2012 年には心安く頼める相手は少なくなり, 弱 いつながりをも活用して勧誘を行ったということが ヒアリング調査から聞かれた。

一方，N1 は現在の住まいである $\mathrm{N}$ 集落の同学区 である $\mathrm{J}$ 集落の出身者で， $\mathrm{N}$ 集落内の同級生仲間が 集まるためのずぼら会を組織している。ずぼら会で は家族ぐるみの付き合いを行ら関係にあり, 常に顔 を合わし，情報交換を行う関係性にあることから，
頼みやすい二者間関係にあったといえる．D3 は地 区の消防活動に熱心であり，農家民泊の普及にもそ の関係性を生かした，消防活動では，日常的なつな がりが重視され，共有する時間も多いことから， N1 の活動環境と同じく頼みやすい二者間関係に あったと考吕る。

一般的には N1 や D3 のように日常的なつながり が強い中で勧誘されると考光られるが，同地区では D1 と D2 が元町長世帯といら特別なキーパーソン の存在があったために，日常的なつながりが弱くて もリーダー層としての使命感によって農家民泊の普 及につながったと考光られた。

\section{3）年代別にみた普及における二者間関係}

次に農家民泊がぞのような過程で普及したのかい ら点について分析するために，年代別にその特徴を みることにする。

まず年代別に居住地に関する二者間関係をみる.

主要勧誘者 4 名の世帯は 2010 年に自発的に始め 
表 3. 農家民泊開始別にみた居住地の二者間関係

(単位：上段：件数，中段：\%, 下段 : 特化係数)

\begin{tabular}{|c|c|c|c|c|}
\hline \multirow{2}{*}{$\begin{array}{l}\text { 農家民泊 } \\
\text { 開始時期 }\end{array}$} & \multicolumn{3}{|c|}{ 居住地 } & \multirow{2}{*}{ 計 } \\
\hline & 集落内 & 学区内 & 学区外 & \\
\hline \multirow{3}{*}{2010 年 } & 3 & & 2 & 5 \\
\hline & 60.0 & & 40.0 & 100.0 \\
\hline & 2.50 & & 0.83 & 1.00 \\
\hline \multirow{3}{*}{2011 年 } & 3 & 3 & 6 & 12 \\
\hline & 25.0 & 25.0 & 50.0 & 100.0 \\
\hline & 1.04 & 0.89 & 1.04 & 1.00 \\
\hline \multirow{3}{*}{2012 年 } & & 4 & 4 & 8 \\
\hline & & 50.0 & 50.0 & 100.0 \\
\hline & & 1.79 & 1.04 & 1.00 \\
\hline \multirow{3}{*}{ 計 } & 6 & 7 & 12 & 25 \\
\hline & 24.0 & 28.0 & 48.0 & 100.0 \\
\hline & 1.00 & 1.00 & 1.00 & 1.00 \\
\hline
\end{tabular}

資料：ヒアリング調査を基づき筆者作成

註: 愛東地区における主要 4 名との二者間関係である.

表 4. 農家民泊開始別にみた組織活動による二者間 関係

(単位：上段：件数，中段：\%, 下段：特化係数)

\begin{tabular}{|c|c|c|c|}
\hline \multirow{2}{*}{$\begin{array}{l}\text { 農家民泊 } \\
\text { 開始時期 }\end{array}$} & \multicolumn{2}{|c|}{ 二者間関係 } & \multirow[b]{2}{*}{ 計 } \\
\hline & $\begin{array}{l}\text { 組織活動に } \\
\text { よるつながり }\end{array}$ & 個人的つながり & \\
\hline \multirow{3}{*}{2010 年 } & 2 & 3 & 5 \\
\hline & 40.0 & 60.0 & 100.0 \\
\hline & 0.67 & 1.50 & 1.00 \\
\hline \multirow{3}{*}{2011 年 } & 9 & 3 & 12 \\
\hline & 75.0 & 25.0 & 100.0 \\
\hline & 1.25 & 0.63 & 1.00 \\
\hline \multirow{3}{*}{2012 年 } & 4 & 4 & 8 \\
\hline & 50.0 & 50.0 & 100.0 \\
\hline & 0.83 & 1.25 & 1.00 \\
\hline \multirow{3}{*}{ 計 } & 15 & 10 & 25 \\
\hline & 60.0 & 40.0 & 100.0 \\
\hline & 1.00 & 1.00 & 1.00 \\
\hline
\end{tabular}

資料：ヒアリング調査を基づき筆者作成

註: 愛東地区に打垄要 4 名との二者間関係である.

ている. この自発的に始めた事例を除いた二者間関 係を分析すると表 $3 ， 4$ のようになる. 居住地の二 者間関係では, 集落内は 2010 年に特化度合いが強 く，学区内関係，すなわち集落外ではあるが同学区
内は 2012 年に特化度合いが強い. これに対して, 学区外の二者間関係は毎年平均的な割合で確保され ている

一方，開始時期別に個人的つながりによる二者間 関係と組織活動でつながる二者間関係別にみると表 4 のようになる. 2010 年と 2012 年は個人的つなが りによる二者間関係, 2011 年は組織活動による二 者間関係に特化度合いが強い.

つまり，1 年目の 2010 年には自発的に開始した 主要勧誘者 4 名の他，彼らの個人的つながりで同集 落内に住む二者間関係で普及が始まり，2年目の 2011 年には居住地の隣接性よりも組織活動によっ て得た二者間関係で普及し，3 年目の 2012 年には 学区内で個人的つながりの二者間関係で普及してい ることがわかった.

\section{4. 愛東地区における農家民泊の普及}

本研究により住民が主体的に行ら農家民泊の受入 の普及については，主要なキーパーソンと勧誘され る側の二者間関係によって成立して扣り，体験教育 旅行を受入れようとする世帯については，50〜60 歳代の女性が中心的に関わる世帯であることが必要 であると考えられた。この愛東地区に㧤いては，旧 愛東町時代から始まった交流事業によって地区外者 の民泊受入には慣れていたといら背景があったこ と, キーパーソンとして元町長夫妻が普及に果たし た役割が大きいと考えられた。 そのことは地域特性 として踏まえた上で，ヒアリング調査結果から受入 農家民泊の普及過程を年代別にまとめると，図 3 の よらになる。 2010 年と 2012 年の打性人的つな がりの強さが異なっている理由については, 2012 年の勧誘では，勧誘者が過去の経験より，受入可能 性が高いと思われる家族構成の世帯に対し熱心に勧 誘した結果，弱い個人的つながりによる勧誘が増え

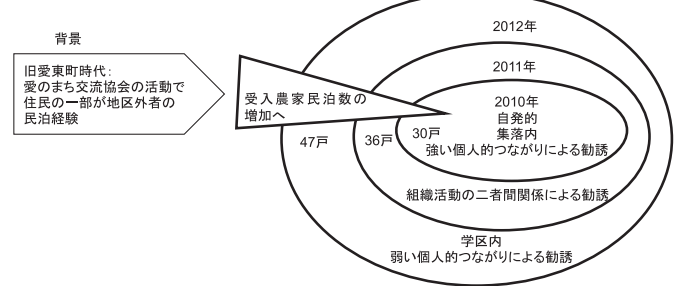

図 3．住民主体による農家民泊の普及過程 資料：筆者作成 
たといらことである. 経験を積み，1回あたりの受 入規模が拡大寸ると, 受入経験のない世帯を勧誘す ることも必要となる。，その時に，各世帯の家族構成 や家庭状況に関する情報を得ておくことが望ましい といらことが本事例より示唆された. また, 表 2 に 示した通り，組織活動による针誘 15 のらち 11 がボ ランティア的活動の組織によるつながりであること から，ボランティア的活動が農家民泊の勧誘に有効 であることも示唆された。

注 1) 山田 (2008a) p. 3 参照.

2）鈴村（2009: p. 41）によれば，小中学生を対象と した農家民泊を含む一連の農林漁業体験プログラ ムを「農林漁業体験教育旅行 $=$ 体験教育旅行」と 位置付けている.

3）都市農山漁村交流活性化機構（2010）に抢ける事 例をみても，行政が空口になって受入れている.

4）「所得の向上」を目的とする回答数は 0 であった. つまり, 当地区での受入世帯は, 農業収入に依存 しない性格が強いことと，1 戸当たりの受入平均 人数が 3.4 人 / 回, 受入平均回数も年間 2.2 回と少 なく，受入による収入が副収入と認識されていな いことが影響していると考えられる.

5）居住地の関係に打ける区分に関して学区という概 念を用いたのは，学区は，小学校単位であり，集 落内ほどの知り合いではなくても, 顔見知りの関 係にある二者間関係はあると考えたからである.

\section{参考・引用文献}

[1] 大江靖雄（1997）「民宿農家の経済特性と機能」 『1997 年度日本農業経済学会論文集』, 118-120.

［2］（財）都市農山漁村交流活性化機構（2010）『平 成 21 年度小学校に打けるふるさと生活体験活 動の取組事例集一受入地域との協同による実 施までの要点と教育的な効果一』.
［3］佐藤真弓（2008）「学校教育に抢故農業・農 村体験の展開と課題」『2008 年度日本農業経 済学会論文集』, 194-201.

[4] 佐藤真弓（2009）「グリーン・ッーリズム農政 の展開と農家民泊」『2009 年度日本農業経済 学会論文集』, 378-385.

［5］佐藤真弓（2010）『都市農村交流と学校教育』, 農林統計出版。

［6］鈴村源太郎（2009）「小中学生の体験教育旅行 受け入れによる農村地域活性化」『農林水産政 策研究』第 15 号，41-59.

［7］鈴村源太郎・中村敏郎（2010）「小学生を対象 とした農林漁家宿泊体験の実態と効果」『2010 年度日本農業経済学会論文集』, 228-235.

［8］中尾誠二（2008）「農林漁家民宿に係る規制緩 和と民泊の位置付济関する一考察」『2008 年度日本農業経済学会論文集』, 186-193.

［9］中尾誠二（2009）「規制緩和型農林漁家民宿に 関する一考察」『2009 年度日本農業経済学会 論文集』，386-393.

［10］農林水産省農村振興局（2008）『農山漁村飞拈 ける宿泊体験活動の受け入れのための手引き 〜子ども農山漁村交流プロジェクト推進に向 けて〜』。

［11］山田伊澄（2008a）「農業体験学習による子ど もの意識・情感への影響に関する実証分析一 実施場所の異なる都市地域の 3 つの小学校を 対象として一」『農林業問題研究』第 171 号, 326-336.

［12］山田伊澄（2008b）「農業・農村体験による子 ぞもの気分状態変化に関する分析」『農林業問 題研究』第 170 号, 181-184.

（受理日：2013 年 3 月 11 日） 